Article

\title{
Bioactive Compounds from the Red Sea Marine Sponge Hyrtios Species
}

\section{Diaa T. A. Youssef ${ }^{1, *}$, Lamiaa A. Shaala ${ }^{2}$ and Hani Z. Asfour ${ }^{3}$}

1 Department of Natural Products, Faculty of Pharmacy, King Abdulaziz University, Jeddah 21589, Kingdom of Saudi Arabia

2 Natural Products Unit, King Fahd Medical Research Center, King Abdulaziz University, Jeddah 21589, Kingdom of Saudi Arabia; E-Mail: 1shalla@kau.edu.sa

3 Department of Medical Parasitology, Faculty of Medicine, Princess Al-Jawhara Center of Excellence in Research of Hereditary Disorders, King Abdulaziz University, Jeddah 21589, Kingdom of Saudi Arabia; E-Mail: hasfour@hotmail.com

* Author to whom correspondence should be addressed; E-Mail: dyoussef@kau.edu.sa; Tel.: +966-548-535-344; Fax: +966-269-516-96.

Received: 17 February 2013; in revised form: 7 March 2013 / Accepted: 15 March 2013 / Published: 28 March 2013

\begin{abstract}
In continuation of our search for drug leads from Red Sea sponges we have investigated the ethyl acetate fraction of the organic extract of the Red Sea sponge Hyrtios species. Bioassay-directed fractionation of the active fraction resulted into the identification of three new alkaloids, hyrtioerectines D-F (1-3). Hyrtioerectines D-F belong to the rare marine alkaloids in which the indole and $\beta$-carboline fragments of the molecule are linked through $\mathrm{C}-3 / \mathrm{C}-3$ of both moieties. The structures of the isolated compounds were established based on different spectroscopic data including UV, IR, 1D and 2D NMR (COSY, HSQC, and HMBC) and high-resolution mass spectral studies. The antimicrobial activity against several pathogens and the free radical scavenging activity of the compounds using DPPH reagent were evaluated. In addition, the growth inhibitory activity of the compounds against three cancer cell lines was also evaluated. Hyrtioerectines D-F (1-3) displayed variable antimicrobial, free radical scavenging and cancer growth inhibition activities. Generally, compounds $\mathbf{1}$ and $\mathbf{3}$ were more active than compound $\mathbf{2}$.
\end{abstract}

Keywords: Red Sea sponge; Hyrtios species; alkaloids; antimicrobial activity; free radical scavenging activity; cancer growth inhibition activity 


\section{Introduction}

Sponges belonging to the genus Hyrtios (Demospongiae class, Dictyoceratida order, Thorectidae family) [1] have proven to be a rich source of biologically active diverse secondary metabolites of different classes. Prominent reported classes from this genus include sesterterpenes [2-6], sesquiterpenes [7-9], macrolides [10,11], indole and $\beta$-carboline alkaloids [12-16]. Indole derivatives possess different biological activities including anticancer, antibiotic, anti-inflammatory and antioxidant activities [17,18]. Secondary metabolites of the genus Hyrtios displayed diverse biological activities $[2,3,5,7,10-13,15,19]$. In the course of our ongoing efforts to identify drug leads from Red Sea marine organisms, we investigated the ethyl acetate fraction of an organic extract of the Red Sea marine sponge Hyrtios species.

Chromatographic fractionation and final HPLC purification of the active ethyl acetate fraction resulted into the isolation of three alkaloids, hyrtioerectines D-F (1-3) (Figure 1). The assignment of the structure of the compounds was based on one- and two-dimensional NMR studies including COSY, HSQC, and HMBC together with IR and high-resolution mass spectral studies.

Figure 1. Structures of hyrtioerectines D-F (1-3) isolated from the marine sponge Hyrtios species.

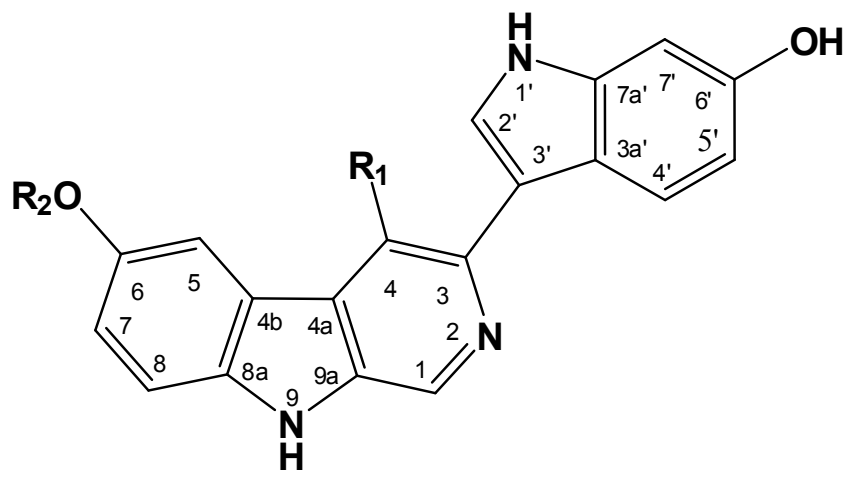

$$
\begin{array}{lll}
1 & \mathbf{R}_{1}=\mathrm{COOH} & \mathrm{R}_{2}=\mathrm{H} \\
2 & \mathrm{R}_{1}=\mathrm{COOH} & \mathbf{R}_{2}=\mathrm{CH}_{3} \\
3 & \mathbf{R}_{1}=\mathrm{CONH} & \mathbf{R}_{2}=\mathrm{H}
\end{array}
$$

\section{Results and Discussion}

\subsection{Purification of Compounds 1-3}

Successive chromatographic fractionation of the antimicrobial ethyl acetate fraction of an organic extract of the Red Sea sponge Hyrtios species using a combination of liquid-liquid partition, size exclusion chromatography on Sephadex LH-20 and final HPLC purification of the active fraction on C18 HPLC column afforded three new alkaloids hyrtioerectines D-F (1-3). The structure determination of the compounds was assigned from one- and two-dimensional NMR and high-resolution mass spectral studies. 


\subsection{Structure Elucidation of Compounds $\mathbf{1}-\mathbf{3}$}

The HRMS of compound 1 established a molecular formula $\mathrm{C}_{20} \mathrm{H}_{13} \mathrm{~N}_{3} \mathrm{O}_{4}$ requiring 16 degrees of unsaturation. Compound 1 gave a bluish color on the TLC with $\mathrm{FeCl}_{3}$ indicating its phenolic nature. Its ${ }^{1} \mathrm{H}$ NMR spectrum (in methanol- $d_{4}$, Table 1 ) showed resonances for eight aromatic protons ranging from 6.80 to $9.64 \mathrm{ppm}$, suggesting the absence of any aliphatic moiety in the molecule. The ${ }^{13} \mathrm{C} \mathrm{NMR}$ spectrum of 1 (Table 1) displayed resonances for 20 carbons including 8 methines and 12 quaternary carbons. Two of the ${ }^{13} \mathrm{C}$ quaternary resonances were deshielded at $\delta 154.3(\mathrm{C}-6)$ and $153.0\left(\mathrm{C}-6^{\prime}\right)$ suggesting the oxygenation of their corresponding carbons. Interpretation of the $1 \mathrm{D}\left({ }^{1} \mathrm{H}\right.$ and $\left.{ }^{13} \mathrm{C}\right)$ and $2 \mathrm{D}$ $\left({ }^{1} \mathrm{H}-{ }^{1} \mathrm{H}\right.$ COSY, HSQC and HMBC) NMR spectroscopic data supported the presence of two ABX systems for trisubstituted $\beta$-carboline (H-5, H-7 and H-8) and disubstituted indole (H-4', H-5' and H-7') moieties, respectively. These two moieties include 15 degrees of unsatuartion suggesting the need for an additional degree of unsaturation in 1. Interpretation of the NMR data $\left({ }^{1} \mathrm{H}, \mathrm{COSY}\right.$ and HSQC $)$ supported the 3,4,6-trisubstitution of the $\beta$-carboline moiety. This was evident from the resonating signals at $\delta 8.07$ $(1 \mathrm{H}, \mathrm{d}, J=2.0, \mathrm{H}-5), 6.80(1 \mathrm{H}, \mathrm{dd}, J=8.5,2.0, \mathrm{H}-7), 7.30(1 \mathrm{H}, \mathrm{d}, J=8.5, \mathrm{H}-8)$ and $9.64(\mathrm{~s}, \mathrm{H}-1)$. Additional signals at $\delta 8.87\left(1 \mathrm{H}, \mathrm{s}, \mathrm{H}-2^{\prime}\right), 7.57\left(1 \mathrm{H}, \mathrm{d}, J=8.7, \mathrm{H}-4^{\prime}\right), 7.13\left(1 \mathrm{H}, \mathrm{dd}, J=8.7,2.3, \mathrm{H}-5^{\prime}\right)$ and $7.60\left(1 \mathrm{H}, \mathrm{d}, J=2.3, \mathrm{H}-7^{\prime}\right)$ were assigned as 3,6-disubstituted indole moiety. The HSQC experiment allowed the unambiguous assignment of the protonated methine carbons in $\mathbf{1}$ (Table 1). The quaternary carbons were unambiguously assigned from HMBC data (Table 2 and Figure 2). For example, the location of the $\mathrm{OH}$ moieties at C-6 and C-6' was supported from HMBC correlations of H-5/C-6, H-7/C-6, H-8/C-6 and H-4'/C-6', H-5'/C-6' and H-7'/C-6' (Table 2). The connection of the indole and $\beta$-carboline moieties through C-3 and C-3' was supported from a ${ }^{3} J_{\mathrm{CH}}$ HMBC cross peak between $\mathrm{H}-2^{\prime}$ of the indole moiety $(\delta 8.87)$ and $\mathrm{C}-3$ of the $\beta$-carboline moiety $(\delta 138.1)$. Finally, the quaternary carbon resonating at $\delta 173.0\left(\mathrm{C}-8^{\prime}\right)$ was assigned as a carboxylic moiety at C-4 completing the degrees of unsaturation in 1. This was supported by an IR band at $1725 \mathrm{~cm}^{-1}$ for the carbonyl moiety of the carboxylic acid. Furthermore, the MS fragment ion at $m / z 315.1009$ with the molecular formula $\mathrm{C}_{19} \mathrm{H}_{13} \mathrm{~N}_{3} \mathrm{O}_{2}[\mathrm{M}-\mathrm{COOH}+\mathrm{H}]^{+}$supported the presence of the carboxylic functionality, thus completing the assignment of $\mathbf{1}$.

Compound 2 displayed a pseudomolecular ion peak at $m / z 374.1138$ corresponding to $\mathrm{C}_{21} \mathrm{H}_{16} \mathrm{~N}_{3} \mathrm{O}_{4}$ $[\mathrm{M}+\mathrm{H}]^{+}$, being 14 mass unit $\left(\mathrm{CH}_{2}\right)$ more than 1 and requiring 16 degrees of unsaturation. Comparison of the NMR data of $\mathbf{2}$ with those of $\mathbf{1}$ showed identical similarity of the ${ }^{1} \mathrm{H}$ and ${ }^{13} \mathrm{C}$ NMR resonances of both compounds (Table 1). Moreover, a new three-proton singlet in ${ }^{1} \mathrm{H}$ NMR at $\delta 3.84\left(\mathrm{H}_{3}-9^{\prime}\right)$ correlates in the HSQC with the ${ }^{13} \mathrm{C}$ NMR signal at $\delta 55.8$ (C-9') suggesting the presence of a methoxyl moiety in 2 at C-6. The assignment of the methoxyl moiety at C-6 was secured from HMBC cross peak of $\mathrm{OCH}_{3} / \mathrm{C}-6$ (Table 2). Additionally, the unambiguous assignments of the protonated and quaternary carbons in $\mathbf{2}$ were secured from HSQC and HMBC experiments, respectively, thus completing the assignment of 2 . 
Table 1. NMR spectroscopic data for hyrtioerectines D-F (1-3) (in methanol- $\left.d_{4}\right)$.

\begin{tabular}{|c|c|c|c|c|c|c|}
\hline \multirow[b]{2}{*}{ Position } & \multicolumn{2}{|c|}{ Hyrtioerectine D } & \multicolumn{2}{|c|}{ Hyrtioerectine E } & \multicolumn{2}{|c|}{ Hyrtioerectine F } \\
\hline & $\delta_{C}(\text { mult. })^{a}$ & $\begin{array}{l}\delta_{\mathrm{H}}, \text { mult. } \\
(\mathrm{J} \text { in } \mathrm{Hz})\end{array}$ & $\delta_{\mathrm{C}}(\text { mult. })^{\mathrm{a}}$ & $\begin{array}{l}\delta_{\mathrm{H}}, \text { mult. } \\
(\mathrm{J} \text { in } \mathrm{Hz})\end{array}$ & $\delta_{\mathrm{C}}(\text { mult. })^{\mathrm{a}}$ & $\begin{array}{l}\delta_{\mathrm{H}}, \text { mult. } \\
(\mathrm{J} \text { in } \mathrm{Hz})\end{array}$ \\
\hline 1 & $140.8(\mathrm{CH})$ & $9.64, \mathrm{~s}$ & $141.2(\mathrm{CH})$ & $9.66, \mathrm{~s}$ & $139.6(\mathrm{CH})$ & $9.71, \mathrm{~s}$ \\
\hline 3 & $138.1(\mathrm{qC})$ & & $138.2(\mathrm{qC})$ & & $138.3(\mathrm{qC})$ & \\
\hline 4 & $138.8(\mathrm{qC})$ & & $138.8(\mathrm{qC})$ & & $138.8(\mathrm{qC})$ & \\
\hline $4 a$ & $115.9(\mathrm{qC})$ & & $115.8(\mathrm{qC})$ & & $115.9(\mathrm{qC})$ & \\
\hline $4 \mathrm{~b}$ & $130.1(\mathrm{qC})$ & & $130.3(\mathrm{qC})$ & & $130.4(\mathrm{qC})$ & \\
\hline 5 & $108.2(\mathrm{CH})$ & $8.07, \mathrm{~d}(2.0)$ & $110.1(\mathrm{CH})$ & $8.10, \mathrm{~d}(2.2)$ & $107.2(\mathrm{CH})$ & $8.09, \mathrm{~d}(2.2)$ \\
\hline 6 & $154.3(\mathrm{qC})$ & & $156.2(\mathrm{qC})$ & & $154.2(\mathrm{qC})$ & \\
\hline 7 & $113.5(\mathrm{CH})$ & $6.80, \mathrm{dd}(8.5,2.0)$ & $113.5(\mathrm{CH})$ & $6.78, \mathrm{dd}(8.5,2.2)$ & $113.7(\mathrm{CH})$ & $6.76, \mathrm{dd}(8.5,2.2)$ \\
\hline 8 & $113.1(\mathrm{CH})$ & $7.30, \mathrm{~d}(8.5)$ & $113.1(\mathrm{CH})$ & $7.27, \mathrm{~d}(8.5)$ & $113.5(\mathrm{CH})$ & 7.32, d (8.5) \\
\hline $8 a$ & $132.1(\mathrm{qC})$ & & $132.2(\mathrm{qC})$ & & $132.4(\mathrm{qC})$ & \\
\hline $9 a$ & $133.2(\mathrm{qC})$ & & $133.1(\mathrm{qC})$ & & $133.2(\mathrm{qC})$ & \\
\hline $2^{\prime}$ & $119.6(\mathrm{CH})$ & $8.87, \mathrm{~s}$ & $119.5(\mathrm{CH})$ & $8.88, \mathrm{~s}$ & $119.6(\mathrm{CH})$ & $8.87, \mathrm{~s}$ \\
\hline $3^{\prime}$ & $123.2(\mathrm{qC})$ & & $123.2(\mathrm{qC})$ & & $123.2(\mathrm{qC})$ & \\
\hline $3 a^{\prime}$ & $137.5(\mathrm{qC})$ & & $137.5(\mathrm{qC})$ & & $137.5(\mathrm{qC})$ & \\
\hline $4^{\prime}$ & $114.1(\mathrm{CH})$ & $7.57, \mathrm{~d}(8.7)$ & $114.1(\mathrm{CH})$ & 7.61, d (8.7) & $114.1(\mathrm{CH})$ & 7.64, d (8.0) \\
\hline $5^{\prime}$ & $119.7(\mathrm{CH})$ & $7.13, \mathrm{dd}(8.7,2.3)$ & $119.6(\mathrm{CH})$ & $7.15, \mathrm{dd}(8.7,2.2)$ & $119.7(\mathrm{CH})$ & $7.17, \mathrm{dd}(8.7,2.0)$ \\
\hline $6^{\prime}$ & $153.0(\mathrm{qC})$ & & $153.1(\mathrm{qC})$ & & $153.0(\mathrm{qC})$ & \\
\hline $7^{\prime}$ & $106.7(\mathrm{CH})$ & $7.60, \mathrm{~d}(2.3)$ & $106.9(\mathrm{CH})$ & 7.62, d (2.2) & $106.7(\mathrm{CH})$ & $7.65, \mathrm{~d}(2.0)$ \\
\hline $7 a^{\prime}$ & $132.6(\mathrm{qC})$ & & $132.5(\mathrm{qC})$ & & $132.6(\mathrm{qC})$ & \\
\hline $8^{\prime}$ & $173.0(\mathrm{qC})$ & & $173.0(\mathrm{qC})$ & & $164.2(\mathrm{qC})$ & \\
\hline $9^{\prime}$ & & & $55.8\left(\mathrm{CH}_{3}\right)$ & $3.84, \mathrm{~s}$ & & \\
\hline
\end{tabular}

${ }^{\mathrm{a}}$ multiplicities of the signals were obtained from HSQC experiments; $\mathrm{qC}=$ quaternary carbon, $\mathrm{CH}=$ methine; $\mathrm{CH}_{3}=$ methyl.

Figure 2. COSY and HMBC correlations observed for compound 1.

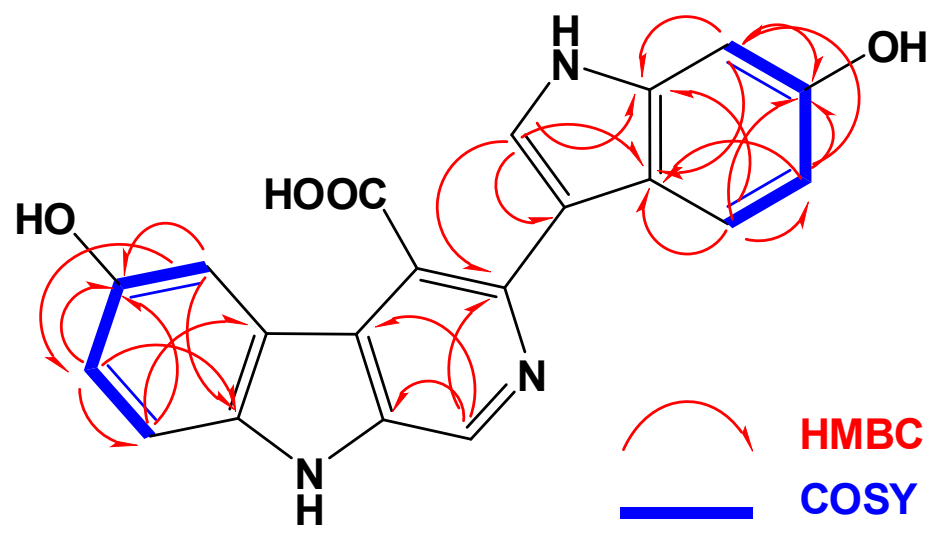


Table 2. Selected HMBC correlations for hyrtioerectines D-F (1-3) (in methanol- $\left.d_{4}\right)$.

\begin{tabular}{|c|c|c|c|}
\hline \multirow{2}{*}{ C\# } & Hyrtiooerectine D (1) & Hyrtioerectine E (2) & Hyrtioerectine F (3) \\
\hline & HMBC $(\mathrm{H} \rightarrow \mathrm{C \#})$ & HMBC $(\mathrm{H} \rightarrow \mathrm{C \#})$ & HMBC $(\mathrm{H} \rightarrow \mathrm{C \#})$ \\
\hline 3 & H-1, H-2' & H-1, H-2' & H-1, H-2' \\
\hline 4 & - & - & - \\
\hline $4 \mathrm{a}$ & $\mathrm{H}-1, \mathrm{H}-5$ & $\mathrm{H}-1$ & $\mathrm{H}-1, \mathrm{H}-5$ \\
\hline $4 \mathrm{~b}$ & $\mathrm{H}-8$ & $\mathrm{H}-8$ & $\mathrm{H}-8$ \\
\hline 5 & $\mathrm{H}-7$ & $\mathrm{H}-7$ & $\mathrm{H}-7$ \\
\hline 6 & H-5, H-7, H-8 & $\mathrm{H}-5, \mathrm{H}-7, \mathrm{H}-8, \mathrm{H}_{3}-9^{\prime}$ & $\mathrm{H}-5, \mathrm{H}-8$ \\
\hline 7 & $\mathrm{H}-5$ & $\mathrm{H}-5$ & $\mathrm{H}-5$ \\
\hline 8 & $\mathrm{H}-7$ & $\mathrm{H}-7$ & $\mathrm{H}-7$ \\
\hline $8 \mathrm{a}$ & $\mathrm{H}-5, \mathrm{H}-7$ & $\mathrm{H}-5, \mathrm{H}-7$ & $\mathrm{H}-5, \mathrm{H}-7$ \\
\hline $9 \mathrm{a}$ & $\mathrm{H}-1$ & $\mathrm{H}-1$ & $\mathrm{H}-1$ \\
\hline $2^{\prime}$ & - & - & - \\
\hline $3^{\prime}$ & $\mathrm{H}-2^{\prime}$ & $\mathrm{H}-2^{\prime}$ & $\mathrm{H}-2^{\prime}$ \\
\hline $3 a^{\prime}$ & H-2', H-4', H-5', H-7' & H-2', H-4', H-7' & H-2', H-4', H-7' \\
\hline $4^{\prime}$ & $\mathrm{H}-5^{\prime}$ & $\mathrm{H}-5^{\prime}$ & $\mathrm{H}-5^{\prime}$ \\
\hline $5^{\prime}$ & $\mathrm{H}-4^{\prime}, \mathrm{H}-7^{\prime}$ & $\mathrm{H}-4^{\prime}, \mathrm{H}-7^{\prime}$ & $\mathrm{H}-4^{\prime}, \mathrm{H}-7^{\prime}$ \\
\hline $6^{\prime}$ & H-4', H-5', H-7' & H-4', H-5', H-7' & H-4', H-5', H-7' \\
\hline $7^{\prime}$ & $\mathrm{H}-5^{\prime}$ & H-5' & H-5' \\
\hline $7 a^{\prime}$ & H-2', H-4', H-7' & H-2', H-4', H-7' & H-2', H-4', H-7' \\
\hline
\end{tabular}

Compound 3 displayed a pseudomolecular ion peak at $\mathrm{m} / z 359.1142$ corresponding to $\mathrm{C}_{20} \mathrm{H}_{15} \mathrm{~N}_{4} \mathrm{O}_{3}$ $[\mathrm{M}+\mathrm{H}]^{+}$, being one mass unit less than $\mathbf{1}$ and requiring the same degrees of unsaturation. Again, comparison of the NMR data of $\mathbf{3}$ with those of $\mathbf{1}$ showed close similarity of two compounds (Table 1). The presence of the amide moiety in $\mathbf{3}$ instead of the carboxylic moiety in $\mathbf{1}$ was supported by the upfield amidic carbonyl resonance at $\delta 164.2$ instead of $173.0 \mathrm{ppm}$ in 1 . In addition, IR band at $1655 \mathrm{~cm}^{-1}$ supported the presence of an amidic carbonyl in 3. Again, the assignments of all quaternary carbons were secured from HMBC cross peaks (Table 2) completing the assignment of $\mathbf{3}$.

Hyrtioerectines D-F (1-3) represent additional candidates of the rare alkaloids in which the indole and $\beta$-carboline fragments are linked through $\mathrm{C}-3$ of both moieties. We have previously reported one compound of this series, hyrtioerectine A [12]. Additional member of this class including eudistomin $\mathrm{U}$ was reported from the Caribbean ascidian Lissoclinum fragile [20]. However, the linkage of the $\beta$-carboline and indole fragments in eudistomin $\mathrm{U}$ occurs between $\mathrm{C}-1$ and $\mathrm{C}-3$, respectively. In the case of hyrtioerectines, the linkage occurs between C-3 and C-3 of both moieties.

Compounds 1-3 were evaluated for their antimicrobial, free radical scavenging activity as well as cancer growth inhibition activity against three cancer cell lines. In the antimicrobial assay, compounds 1-3 displayed inhibition zones of 17, 9 and $14 \mathrm{~mm}$ against Candida albicans compared to $35 \mathrm{~mm}$ illustrated by clotrimazole at the same concentration. Furthermore, compounds $\mathbf{1}-\mathbf{3}$ showed inhibition zones of 20, 10 and $16 \mathrm{~mm}$ against Staphylococcus aureus, respectively, compared to $30 \mathrm{~mm}$ illustrated by ampicillin. Finally, compounds 1-3 displayed weak inhibition zones of 7-9 mm against Pseudomonas aeruginosa compared to $30 \mathrm{~mm}$ illustrated by imipenem and were inactive against $E$. coli. 
In the free radical scavenging activity assay using DPPH, compounds $\mathbf{1}$ and $\mathbf{3}$ were the most active compounds with $45 \%$ and $42 \%$ inhibition, respectively, while compound 2 were moderately active with 31\% inhibition. Compounds 1-3 were evaluated for in vitro growth inhibition of lung carcinoma (A549), colorectal carcinoma (HT29), and breast adenocarcinoma (MDA-MB-231) cells (Table 3). Compounds 1-3 exhibited variable activity with $\mathrm{GI}_{50}$ values (the concentration required to achieve $50 \%$ growth inhibition of the cells) in the micromolar range and no selectivity between the cell lines tested. While compounds $\mathbf{1}$ and $\mathbf{3}$ were slightly more cytotoxic than compounds $\mathbf{2}$, the compounds were more than 75-100 times less potent than the positive control doxorubicin (Table 3).

In conclusion, the relatively higher antimicrobial, free radical scavenging and growth inhibition activities of compounds $\mathbf{1}$ and $\mathbf{3}$ over $\mathbf{2}$ in could be attributed to the presence of diphenolic moieties in $\mathbf{1}$ and 3. The amidation of the carboxylic moiety in $\mathbf{3}$ seems to have a slight effect on the activity if compared to 1 .

Table 3. Cancer cell line inhibition by hyrtioerectines D-F (1-3).

\begin{tabular}{cccc}
\hline \multirow{2}{*}{ Compound } & \multicolumn{3}{c}{ Cell line $\left[\mathbf{G I}_{\mathbf{5 0}}(\boldsymbol{\mu M})\right]$} \\
\cline { 2 - 4 } & MDA-MB-231 & $\mathbf{A 5 4 9}$ & HT-29 \\
\hline Compound 1 & 25 & 30 & 28 \\
Compound 2 & 90 & 100 & 85 \\
Compound 3 & 42 & 35 & 45 \\
Doxorubicin $^{\text {a }}$ & 0.30 & 0.35 & 0.40 \\
\hline
\end{tabular}

${ }^{\mathrm{a}}$ Positive antiproliferative control.

\section{Experimental Section}

\subsection{General Experimental Procedures}

UV spectra were recorded on a Hitachi 300 spectrometer. IR spectra were recorded on a Perkin-Elmer 1310/84 Spectrometer. NMR spectra were obtained in $\mathrm{CD}_{3} \mathrm{OD}$ on Bruker Avance DRX 400 Spectrometers at $400 \mathrm{MHz}$ for ${ }^{1} \mathrm{H}$ NMR and $100 \mathrm{MHz}$ for ${ }^{13} \mathrm{C}$ NMR. NMR chemical shifts are expressed in parts per million (ppm) referenced to $\mathrm{CD}_{3} \mathrm{OD}$ solvent signals $\left(\delta 3.29\right.$ for ${ }^{1} \mathrm{H}$ and $\delta 49.0$ for ${ }^{13} \mathrm{C}$ ). ESI-MS spectral data were obtained with a Micromass Q-tof equipped with lockspray mass spectrometer using Leucine Enkaphalin at $m / z 556.2771[\mathrm{M}+\mathrm{H}]^{+}$as a reference mass. For column chromatography, silica gel (Merck, 70-230 mesh ASTM) and Sephadex LH-20 (Pharmacia) were used. Pre-coated silica gel 60 F-254 plates (Merck) were used for TLC. DPPH was purchased from Sigma Aldrich, USA.

\subsection{Animal Specimen}

Specimen of the Red Sea sponge Hyrtios species (class Demospongiae, order Dictyoceratida, family Thorectidae) was collected from the Red Sea using SCUBA at depths between 10 and $18 \mathrm{~m}$ in 2011 . The sponge was kindly identified by Dr. Rob van Soest. A voucher specimen was kept in our Red Sea Marine Invertebrates Collection under the registration number DY2011-49. The sponge forms pinkish-gray tubes, diameter of $4.5-5.0 \mathrm{~cm}$, walls $0.5-1.0 \mathrm{~cm}$ thick. The inner lumen measures about $3.0 \mathrm{~cm}$ in diameter, with a smaller side tube of $2.0 \mathrm{~cm}$ diameter and lumen of $1.0 \mathrm{~cm}$. The larger tube is about 
$8.0 \mathrm{~cm}$ high. Surface of the sponge is densely conulose, with blunt conules of $1.0 \mathrm{~mm}$ high, and $1.0-2.0 \mathrm{~mm}$ apart. The consistency is firm, crumbly, and sandy. The skeleton is dense, anisotropic, and consisting of sand-filled primary and secondary fibers, near the surface forming fascicles. Individual primary fibers measure 220-385 $\mu \mathrm{m}$ in diameter, and secondary fibers with diameter of 100-130 $\mu \mathrm{m}$. Meshes polygonal or rounded with $250-1000 \mu \mathrm{m}$ in diameter. Between the fibers the mesophyl is lightly charged with debris and sand grains. The surface aspect and skeletal characters conform to the genus Hyrtios (class Demospongiae, order Dictyoceratida, family Thorectidae), but there are no matching descriptions at the species level for this sponge. The voucher is kept in the collections of the Zoological Museum of the University of Amsterdam, under registration No. ZMA POR. 17249.

\subsection{Extraction and Purifications of Compounds 1-3}

The lyophilized sponge materials $(170 \mathrm{~g})$ were extracted three times $(3 \times 500 \mathrm{~mL})$ with a mixture of methanol/dichloromethane (1:1) at room temperature. The combined organic extracts were concentrated under reduced pressure and suspended in $400 \mathrm{~mL}$ of methanol/water (9:1). The resulted mixture was extracted with $n$-hexane $(3 \times 300 \mathrm{~mL})$ to give $1.9 \mathrm{~g}$ of $n$-hexane extract. The remaining methanolic layer was diluted with water to $(3: 2)$ methanol/water and then extracted successively with dichloromethane $(3 \times 300 \mathrm{~mL})$, ethyl acetate $(3 \times 300 \mathrm{~mL})$ and finally with $n$-butanol $(3 \times 300 \mathrm{~mL})$. Each of the extracts was concentrated under reduced pressure to give $1.2 \mathrm{~g}$ of $\mathrm{CH}_{2} \mathrm{Cl}_{2}$ extract, $530 \mathrm{mg}$ of ethyl acetate extract and $3.8 \mathrm{~g}$ of $n$-butanol extract, respectively. All fractions were evaluated for antimicrobial and free radical scavenging activity. The ethyl acetate extract showed significant activity in both assays and thus was considered for further purification. The ethyl acetate residue $(530 \mathrm{mg})$ was subjected to size exclusion chromatography on a Sephadex LH-20 column equilibrated with methanol to give five fractions. Fractions 3 and 4 were combined and were subjected to another Sephadex LH-20 column using methanol as an eluting solvent to give 6 subfractions. Subfraction 4 (39 $\mathrm{mg})$ was purified on a semi-preparative $\mathrm{C}_{18}$ HPLC column using $20 \%$ acetonitrile in water at a flow rate of $2 \mathrm{~mL} / \mathrm{min}$ to give compound 2 (4.3 mg). Subfraction 5 (33 mg) was subjected to final purification on a semi-preparative $\mathrm{C}_{18}$ HPLC column using $15 \%$ acetonitrile at a flow rate of $2 \mathrm{~mL} / \mathrm{min}$ to afford compounds $1(2.1 \mathrm{mg})$ and $3(1.8 \mathrm{mg})$.

Hyrtioerectine D (1): yellow solid; UV (MeOH) $\lambda_{\max }(\log \varepsilon) 387 \mathrm{~nm}(3.85), 248 \mathrm{~nm}(3.85), 312 \mathrm{~nm}$ (4.05); IR $v_{\max }$ (film) 3600, 3500, 3020, 2980, 1725, 1610, 1405, 1290, 1255, 1220, $890 \mathrm{~cm}^{-1}$; NMR data, see Tables 1 and 2; positive HRESIMS $m / z 360.0981$ (calcd for $\mathrm{C}_{20} \mathrm{H}_{14} \mathrm{~N}_{3} \mathrm{O}_{4}[\mathrm{M}+\mathrm{H}]^{+}, 360.0984$ ).

Hyrtioerectine E (2): yellow solid; UV (MeOH) $\lambda_{\max }(\log \varepsilon) 420 \mathrm{~nm}(3.90), 252 \mathrm{~nm}$ (3.95), $315 \mathrm{~nm}$ (4.15); IR $v_{\max }$ (film) 3595, 3545, 3015, 2980, 1720, 1612, 1410, 1290, 1250, 1220, $895 \mathrm{~cm}^{-1}$; NMR data, see Tables 1 and 2; positive HRESIMS $m / z 374.1138$ (calcd for $\mathrm{C}_{21} \mathrm{H}_{16} \mathrm{~N}_{3} \mathrm{O}_{4}[\mathrm{M}+\mathrm{H}]^{+}, 374.1140$ ).

Hyrtioerectine F (3): yellow solid; UV (MeOH) $\lambda_{\max }(\log \varepsilon) 380 \mathrm{~nm}(3.95), 240 \mathrm{~nm}(4.10), 315 \mathrm{~nm}$ (4.00); IR $v_{\max }$ (film) 3590, 3500, 3350, 3010, 2985, 1655, 1615, 1405, 1290, 1255, 1215, $895 \mathrm{~cm}^{-1}$; NMR data, see Tables 1 and 2; positive HRESIMS $m / z 359.1142$ (calcd for $\mathrm{C}_{20} \mathrm{H}_{15} \mathrm{~N}_{4} \mathrm{O}_{3}[\mathrm{M}+\mathrm{H}]^{+}, 359.1144$ ). 


\subsection{Biological Evaluation of the Compounds}

\subsubsection{Determination of the Antimicrobial Activity}

The compounds were evaluated for their antimicrobial activity against a Gram positive bacterium (Staphylococcus aureus ATCC 6538), two Gram negative bacteria (Escherichia coli ATCC 8739), Pseudomonas aeruginosa ATCC 9027) and a yeast (Candida albicans ATCC 2091) using agar diffusion method. Accurately weighed $1 \mathrm{mg}$ of test compound was dissolved in $1 \mathrm{~mL}$ DMF and $100 \mu \mathrm{L}$ of the solution were inserted in the cups then incubated at $37^{\circ} \mathrm{C}$ for $24 \mathrm{~h}$. The inhibition zones were measured and compared with the reference antibiotics ampicillin $(10 \mu \mathrm{g} / \mathrm{disc})$, imipenem $(10 \mu \mathrm{g} / \mathrm{disc})$ or the antifungal drug clotrimazole $(10 \mathrm{mg} / \mathrm{mL})$.

\subsubsection{Determination of the Free Radical Scavenging Activity Using DPPH}

Compounds 1-3 were evaluated for their free radical scavenging activity using 2,2-diphenyl-1-picryl hydrazyl (DPPH). DPPH was prepared as $6 \times 10^{-5} \mathrm{M}$ solution in methanol, protected from light and kept in refrigerator. Aliquots of different concentrations from each compound were pipetted into a series of $5 \mathrm{~mL}$ volumetric flasks. To each flask $3 \mathrm{~mL}$ of DPPH solution were added, mixed with the solution, volumes were made up with methanol and flasks were allowed to stand in dark at room temperature for $10 \mathrm{~min}$ [21]. The absorbance of each of the resulted solutions was measured at $516 \mathrm{~nm}$ against similarly treated blank. The free radical scavenging activity was determined for each of the compound according to the following equation:

$$
\left[\% \text { DPPH radical scavenging }=\left(A_{0}-A / A_{0}\right) \times 100\right]
$$

where $A_{0}=$ absorbance of a blank, $A=$ absorbance of the sample.

\subsubsection{Cancer Cell Growth Inhibition Assay}

Three cancer cell lines were used in this assay, namely lung carcinoma (A549, ATCC CCL-185), colorectal carcinoma (HT29, ATCC HTB-38), and breast adenocarcinoma cell (MDA-MB-231, ATCC HTB-26). The cancer cell lines were obtained from American Type Culture Collection (ATCC). The cell lines were maintained in RPMI medium supplemented with $10 \%$ fetal calf serum (FCS), $2 \mathrm{mM}$ L-glutamine and $100 \mathrm{U} / \mathrm{mL}$ penicillin and streptomycin, at $37{ }^{\circ} \mathrm{C}$ and $5 \% \mathrm{CO}_{2}$. Triplicate cultures were incubated for $72 \mathrm{~h}$ in the presence or absence of test compounds (at ten concentrations ranging from 10 to $0.0026 \mu \mathrm{g} / \mathrm{mL}$ ). For quantitative estimation of cancer cell growth inhibition, the colorimetric sulforhodamine B (SRB) method was used [22]. Briefly, the cells were washed twice with PBS, fixed for $15 \mathrm{~min}$ in $1 \%$ glutaraldehyde solution, rinsed twice in PBS, and stained in $0.4 \%$ SRB solution for $30 \mathrm{~min}$ at room temperature. The cells were then rinsed several times with $1 \%$ acetic acid solution and air-dried. Sulforhodamine B was then extracted in $10 \mathrm{mM}$ trizma base solution and the absorbance measured at $490 \mathrm{~nm}$. Results are expressed as $\mathrm{GI}_{50}$, the concentration that causes 50\% inhibition in cell growth after correction for cell count at the start of the experiment (NCI algorithm). Doxorubicin and DMSO (solvent) were used as the positive and negative controls in this assay. Prism 3.03 from GraphPad was used for the statistical analysis of the cell growth inhibition results. 


\section{Conclusions}

In conclusion, our search for marine-derived bioactive compounds has led to the investigation of specimen of the Red Sea marine sponge Hyrtios species. Three new alkaloids, hyrtioerectines D-F (1-3), were isolated and their chemical structures were assigned using spectroscopic studies. The alkaloids belong to the rare class in which the indole and the $\beta$-carboline fragments are connected via C-3/C-3 of both moieties. Biological evaluation of the compounds showed that compounds 1-3 possess variable antimicrobial, free radical scavenging and cancer growth inhibition activities.

\section{Acknowledgments}

This paper was funded by the Deanship of Scientific Research (DSR), King Abdulaziz University, Jeddah, under grant No. 1-166-D1432. The authors, therefore, acknowledge with thanks DSR technical and financial support. We thank Rob van Soest for identification of the sponge specimens.

\section{References}

1. Hooper, J.N.A.; van Soest, R.W.M. Systema Porifera: A Guide to the Classification of Sponges; Kluwer Academic/Plenum Publishers: New York, NY, USA, 2002; Volume 1, pp. 1028-1050.

2. Pettit, G.R.; Tan, R.; Cichacz, Z.A. Antineoplastic agents. 542. Isolation and structure of sesterstatin 6 from the Indian Ocean sponge Hyrtios erecta. J. Nat. Prod. 2005, 68, 1253-1255.

3. Youssef, D.T.A.; Shaala, L.A.; Emara, S. Antimycobacterial scalarane-based sesterterpenes from the Red Sea sponge Hyrtios erecta. J. Nat. Prod. 2005, 68, 1782-1784.

4. Qiu, Y.; Deng, Z.; Pei, Y.; Fu, H.; Li, J.; Proksh, P.; Lin, W. Sesterterpenoids from the marine sponge Hyrtios erectus. J. Nat. Prod. 2004, 67, 921-924.

5. Youssef, D.T.A.; Yamaki, R.K.; Kelly, M.; Scheuer, P.J. Salmahyrtisol A, a novel cytotoxic sesterterpene from a Red Sea sponge Hyrtios erecta. J. Nat. Prod. 2002, 65, 2-6.

6. Miyaoka, H.; Nishijima, S.; Mitome, H.; Yamada, Y. Three new scalarane sesterterpenoids from the Okinawan sponge Hyrtios erectus. J. Nat. Prod. 2000, 63, 1369-1372.

7. Youssef, D.T.A.; Singab, A.B.; van Soest, R.W.M.; Fusetani, N. Hyrtiosenolides A and B, two new sesquiterpene $\gamma$-methoxybutenolides and a new sterol from a Red Sea sponge Hyrtios species. J. Nat. Prod. 2004, 67, 1736-1739.

8. Pina, I.C.; Sanders, M.L.; Crews, P. Puupehenone congeners from an Indo-Pacific Hyrtios sponge. J. Nat. Prod. 2003, 66, 2-6.

9. Salmoun, M.; Devijver, C.; Daloze, D.; Braekman, J.-C.; Gomez, R.; de Kluijver, M.; van Soest, R.W.M. New sesquiterpenes/quinones from two sponges of the genus Hyrtios. J. Nat. Prod. 2000, 63, 452-456.

10. Kobayashi, M.; Aoki, S.; Sakai, H.; Kawazoe, K.; Kihara, N.; Sasaki, T.; Kitagawa, I. Altohyrtin A, a potent anti-tumor macrolide from the Okinawan marine sponge Hyrtios altum. Tetrahedron Lett. 1993, 34, 2795-2798.

11. Kobayashi, M.; Aoki, S.; Sakai, H.; Kawazoe, K.; Kihara, N.; Sasaki, T.; Kitagawa, I. Altohyrtins $\mathrm{B}$ and $\mathrm{C}$ and 5-desacetylalthyrtin A, potent cytotoxic macrolide congeners of altohyrtin A, from the Okinawan marine sponge Hyrtios altum. Chem. Pharm. Bull. 1993, 41, 989-991. 
12. Youssef, D.T.A. Hyrtioerectines A-C, cytotoxic alkaloids from the Red Sea sponge Hyrtios erectus. J. Nat. Prod. 2005, 68, 1416-1419.

13. Sauleau, P.; Martin, M.; Dau, M.T.H.; Youssef, D.T.A.; Bourguet-Kondracki, M. Hyrtiazepine, an azepino-indole-type alkaloid from the Red Sea marine sponge Hyrtios erectus. J. Nat. Prod. 2006, 69, 1676-1679

14. Salmoun, M.; Devijver, C.; Daloze, D.; Braekman, J.-C.; van Soest, R.W.M. 5-Hydroxytry ptamine-derived alkaloids from two marine sponges of the genus Hyrtios. J. Nat. Prod. 2002, 65, 1173-1176.

15. Aoki, S.; Ye, Y.; Higuchi, K.; Takashima, A.; Tanaka, Y.; Kitagawa, I.; Kobayashi, M. Novel neuronal nitric oxide synthase (nNOS) selective inhibitor, aplysinopsin-type indole alkaloid, from marine sponge Hyrtios erecta. Chem. Pharm. Bull. 2001, 49, 1372-1374.

16. Kobayashi, J.; Murayama, T.; Ishibashi, M.; Kosuge, S.; Takamatsu, M.; Ohizumi, Y.; Kobayashi, H.; Ohta, T.; Nozoe, S.; Sasaki, T. Hyrtiosins A and B, new indole alkaloids from the Okinawan marine sponge Hyrtios erecta. Tetrahedron 1990, 46, 7699-7702.

17. Gul, W.; Hamann, M.T. Indole alkaloid marine natural products: An established source of cancer drug leads with considerable promise for the control of parasitic, neurological and other diseases. Life Sci. 2005, 78, 442-453.

18. Sugiyama, Y.; Ito, Y.; Suzuki, M.; Hirota, A. Indole derivatives from a marine sponge-derived yeast as DPPH radical scavengers. J. Nat. Prod. 2009, 72, 2069-2071.

19. Pettit, G.R.; Cichacz, Z.A.; Gao, F.; Herald, C.L.; Boyd, M.R.; Schmidt, J.M.; Hooper, J.N.A. Antineoplastic agents. 257. Isolation and structure of spongistatin 1. J. Org. Chem. 1993, 58, 1302-1304.

20. Badre, A.; Boulanger, A.; Abou-Mansour, E.; Banaigs, B.; Combaut, G.; Francisco, C. Eudistomin $\mathrm{U}$ and isoeudistomin $\mathrm{U}$, new alkaloids from the Carribean ascidian Lissoclinum fragile. J. Nat. Prod. 1994, 57, 528-533.

21. Williams, B.W.; Cuverlier, M.E.; Berset, C. Use of free radical method to evaluate antioxidant activity. Food. Sci. Technol. 1995, 28, 25-30.

22. Skehan, P.; Storeng, R.; Scudiero, D.; Monks, A.; McMahon, J.; Vistica, D.; Warren, J.T.; Bokesch, H.; Kenney, S.; Boyd, M.R. New colorimetric cytotoxicity assay for anticancer-drug screening. J. Natl. Cancer Inst. 1990, 82, 1107-1112.

Samples Availability: Available from the authors.

(C) 2013 by the authors; licensee MDPI, Basel, Switzerland. This article is an open access article distributed under the terms and conditions of the Creative Commons Attribution license (http://creativecommons.org/licenses/by/3.0/). 